\title{
Minimal breast milk transfer of rituximab, a monoclonal antibody used in neurological conditions
}

Kristen M. Krysko, MD, MAS, * Sara C. LaHue, MD, * Annika Anderson, BA, Alice Rutatangwa, DO, MSc, William Rowles, BA, Ryan D. Schubert, MD, Jacqueline Marcus, MD, Claire S. Riley, MD, Carolyn Bevan, MD, MS, Thomas W. Hale, RPh, PhD, and Riley Bove, MD, MSc

Neurol Neuroimmunol Neuroinflamm 2020;7:e637. doi:10.1212/NXI.0000000000000637

e637

\section{Abstract}

\section{Objective}

To determine the transfer of rituximab, an anti-CD20 monoclonal antibody widely used for neurologic conditions, into mature breast milk.

\section{Methods}

Breast milk samples were collected from 9 women with MS who received rituximab 500 or $1,000 \mathrm{mg}$ intravenous once or twice while breastfeeding from November 2017 to April 2019. Serial breast milk samples were collected before infusion and at 8 hours, 24 hours, 7 days, and 18-21 days after rituximab infusion in 4 patients. Five additional patients provided 1-2 samples at various times after rituximab infusion.

\section{Results}

The median average rituximab concentration in mature breast milk was low at $0.063 \mu \mathrm{g} / \mathrm{mL}$ (range $0.046-0.097$ ) in the 4 patients with serial breast milk collection, with an estimated median absolute infant dose of $0.0094 \mathrm{mg} / \mathrm{kg} / \mathrm{d}$ and a relative infant dose (RID) of $0.08 \%$ (range $0.06 \%-0.10 \%$ ). Most patients had a maximum concentration at $1-7$ days after infusion. The maximum concentration occurred in a woman with a single breast milk sample and was $0.29 \mu \mathrm{g} / \mathrm{mL}$ at 11 days postinfusion, which corresponds with an estimated RID of $0.33 \%$. Rituximab concentration in milk was virtually undetectable by 90 days postinfusion.

\section{Conclusions}

We determined minimal transfer of rituximab into mature breast milk. The RID for rituximab was less than $0.4 \%$ and well below theoretically acceptable levels of less than $10 \%$. Low oral bioavailability would probably also limit the absorption of rituximab by the newborn. In women with serious autoimmune neurologic conditions, monoclonal antibody therapy may afford an acceptable benefit to risk ratio, supporting both maternal treatment and breastfeeding.

\author{
Correspondence \\ Dr. Bove \\ riley.bove@ucsf.edu
}

\footnotetext{
*These authors contributed equally to the manuscript.
}

From the Department of Neurology (K.M.K., S.C.L., A.A., A.R., W.R., R.D.S., R.B.), University of California, San Francisco; Weill Institute for Neurosciences (K.M.K., S.C.L., A.A., A.R., W.R., R.D.S., R.B.), Department of Neurology, University of California, San Francisco; Department of Neurology (J.M.), Kaiser Permanente, San Francisco; Department of Neurology (C.S.R.), Columbia University, New York, New York; Department of Neurology (C.B.), Northwestern University, Chicago, Illinois; and Department of Pediatrics (T.W.H.), Texas Tech University School of Medicine, Amarillo. 


\section{Glossary}

ASQ3 = Ages and Stages Questionnaire; AUC = area under the curve; CDC = Centers for Disease Control and Prevention; EDSS = Expanded Disability Status Scale; GI = gastrointestinal; ICC = intraclass correlation coefficient; IV = intravenous; NMOSD = neuromyelitis optica spectrum disorder; RID = relative infant dose; UCSF = University of California, San Francisco.

Neurologic diseases including multiple sclerosis (MS), neuromyelitis optica spectrum disorder (NMOSD), autoimmune encephalitis, myasthenia gravis, and migraine commonly affect women of childbearing age, and monoclonal antibody therapies are becoming increasingly available for these conditions. ${ }^{1-5}$ However, limited data on the safety of medications during breastfeeding force many women to choose between treating their neurologic disease or breastfeeding their infant, despite the many benefits of breastfeeding. ${ }^{6}$

Monoclonal antibodies are appealing options during breastfeeding because immunoglobulin Gs (IgGs) are large molecules with low expected breast milk transfer after the colostrum phase, with IgA the main immunoglobulin in human breast milk. ${ }^{7,8}$ There have been recent efforts to bridge the gap in safety data for monoclonal antibodies during breastfeeding, ${ }^{9,10}$ given their widespread use in neurologic, rheumatologic, gastrointestinal (GI), and oncologic diseases. In fact, the American College of Rheumatology presented guidelines in 2018 discussing use of biologics while breastfeeding, ${ }^{11}$ and in 2019, the American Gastrointestinal Association recommended biologics can be continued while breastfeeding. ${ }^{12}$ In neurology, there are limited data and no guidelines for monoclonal antibody use during breastfeeding.

Rituximab is an anti-CD20 monoclonal $\operatorname{IgG}_{1}$ antibody used widely for neurologic autoimmune conditions and is effective and used off-label for MS and myasthenia gravis. ${ }^{13-15}$ Only a single case report measured rituximab concentration in breast milk, for a woman with vasculitis, and levels were reassuringly low $(\leq 0.6 \mu \mathrm{g} / \mathrm{mL})$. However, sample collection occurred on days 7-10 after infusion, and thus, peak concentration and decline in concentration were not captured. ${ }^{16}$ Herein, we aimed to evaluate the transfer of rituximab into mature breast milk in postpartum patients with MS.

\section{Methods}

\section{Study design and population}

In this prospective cohort, we enrolled women with MS receiving rituximab clinically while breastfeeding or shortly after weaning and who were willing to provide breast milk samples. All participants were enrolled in the University of California, San Francisco (UCSF) pregnancy registry for women with demyelinating diseases, which includes patients followed up at the UCSF MS Center and women followed up at other centers if they seek enrollment in the registry, often facilitated by their neurologist. The samples included in this analysis were collected from November 2017 to April 2019.
Patient demographics, medical history, and peripartum details were obtained through questionnaires, interview, and review of medical records. Medical records were reviewed to collect demographic data, treatment history, rituximab infusion date(s)/time and dose(s), and Expanded Disability Status Scale (EDSS) score before pregnancy. Prospective questionnaires collected pregnancy information including treatment before and during pregnancy, pregnancy complications, delivery information, and breastfeeding status. Interview was used to supplement missing information including breastfeeding information and infusion dates as needed. Data from all sites were collected in the same manner by the UCSF study team after referral to the pregnancy registry by their neurologist.

\section{Standard protocol approvals, registrations, and patient consents}

The UCSF Institutional Review Board approved this study (17-22422). Patients provided informed consent to enter the study and provide breast milk samples.

\section{Breast milk collection}

\section{Feasibility samples}

To evaluate feasibility and validate rituximab concentration assay techniques, we initially collected 1-2 breast milk samples from 4 mothers ( 5 samples total) within 2 weeks after 1 or 2 rituximab infusions of 500 or $1,000 \mathrm{mg}$ intravenous (IV) (feasibility samples).

\section{Serial samples}

We then systematically collected serial breast milk samples preinfusion (drug-naive) and at 8,24 , and 48 hours as well as at $7,18-21$, and 30 days after rituximab 500 or $1,000 \mathrm{mg}$ infusion once or twice when possible in 4 mothers ( 1 of whom had 2 samples as part of feasibility samples).

\section{Delayed samples}

In 2 cases, eligible patients were identified at a timeframe more remote from their rituximab infusion, and to maximize available data, delayed samples from these patients were collected up to 90 days from infusion.

The feasibility, serial, and delayed samples were all assayed in the same batch and are all reported to maximize data.

All samples included mature breast milk, which occurs beginning 14 days postpartum, after the colostrum and transitional phases. Mothers collected breast milk samples $(2-5 \mathrm{cc})$ by pumping milk from the breast into sterile freezer safe breast milk bags (NUK brand). The samples were stored by mothers 
at $4^{\circ} \mathrm{C}$ immediately after collection and then transported locally on dry ice ( $<1$ hour) or shipped overnight in insulated PolarTech shipping containers lined with ThermoSafe PolarPacks to the UCSF, where they were stored at $-80^{\circ} \mathrm{C}$. Samples were transported on dry ice $(<1$ hour $)$ to Marin Biologic Laboratories, Inc., for analysis.

\section{Quantification of rituximab in breast milk}

To determine the breast milk concentration of rituximab, samples were analyzed by Marin Biologic Laboratories (Novato, CA, US) using the Eagle Biosciences rituximab ELISA kit. This ELISA is based on a rituximab-specific mouse monoclonal antibody. Standards and samples were incubated in the microtiter plate coated with a capture antibody. After incubation, the wells were washed, and a horseradish peroxidase-conjugated antihuman IgG monoclonal antibody was added that bound to rituximab. After incubation, the wells were washed, and the bound enzymatic activity was detected by addition of chromogensubstrate. The color was proportional to the amount of rituximab in the sample or standard; the optical density was measured using a spectrophotometer at $450 \mathrm{~nm}$. Rituximab concentrations of samples were determined by using the standard curve and measured in $\mathrm{ng} / \mathrm{mL}$ and were then converted to $\mu \mathrm{g} / \mathrm{mL}$ for analyses and reporting for ease of interpretation.

In an initial qualification experiment to test the ELISA kit, 3 standard curves were prepared with drug-naive milk specimens using 3 different conditions (kit standard prepared in dilution buffer, in neat naive milk, and in naive milk diluted 1:10 in a dilution buffer). Recovery of the rituximab standard was similar in all conditions. The method of testing clinical samples neat or at various dilutions and determining $\mathrm{ng} / \mathrm{mL}$ values from the standard curve in kit buffer was also qualified by testing 5 feasibility clinical samples neat and at 1:1,1:10, and 1:30 dilution in kit buffer, with analysis against standard curves prepared in buffer in neat milk or in 1:10 milk. Because there was no statistical difference between the methods of analysis, the final experiment testing concentrations reported in this study tested the samples neat.

Two breast milk concentrations were measured on each sample in duplicate, and the intraclass correlation coefficient (ICC) was calculated to evaluate reproducibility. The 2 replicates were averaged for the final breast milk concentration for each sample.

\section{Statistical analysis}

For the 4 women who provided serial (at least 5) samples, the breast milk concentrations of rituximab were analyzed with pharmacokinetic methods using STATA 15 (College Station, TX). The trapezoidal rule was used to calculate the area under the breast milk concentration-time curves (AUC) for each of these women. The average concentration of rituximab in breast milk $\left(\mathrm{C}_{\text {avg }}\right)$ was calculated by dividing the AUC by the number of days from infusion at the time of the last breast milk sample for each woman. We also determined the maximum concentration $\left(\mathrm{C}_{\max }\right)$ and the time of the maximum concentration for each woman.

The absolute average and maximum rituximab dose to the infant in a 24-hour period and the relative infant dose (RID) were calculated using methods described by Bennett. ${ }^{17}$ The actual maternal weight at the time or closely after the infusion was used for each woman. Calculation of the absolute average and maximum dose and the RID assumes the infant will ingest approximately $150 \mathrm{cc} / \mathrm{kg} / \mathrm{d}$ of breast milk over a typical 24-hour period. The absolute average infant dose over 24 hours is calculated by multiplying the $C_{\text {avg }}$ by 150 $\mathrm{cc} / \mathrm{kg} / \mathrm{d}$, whereas the maximum absolute infant dose is calculated by multiplying $\mathrm{C}_{\max }$ by $150 \mathrm{cc} / \mathrm{kg} / \mathrm{d}$. The RID estimates the infant's exposure to rituximab as a percentage of the maternal dose over a 24-hour period and is calculated by taking the $\mathrm{C}_{\text {avg }}$ in $\mathrm{mg} / \mathrm{L}$, multiplying by $0.15 \mathrm{~L} / \mathrm{kg} / \mathrm{d}$ of breast milk and by the maternal weight, and then dividing by the maternal dose. The RID was also calculated using $C_{\max }$ to determine the maximum RID based on data collected. It has previously been reported by Bennett ${ }^{17}$ that a RID less than $10 \%$ is generally safe for an infant to breastfeed, although toxicity of the specific drug should also be considered.

Median and range were then calculated for these measures across the women who provided serial samples. Although the rituximab concentrations in the women who provided 1-2 samples (feasibility and delayed samples) were not included in these calculations, they also contributed to our overall understanding of rituximab transfer into breast milk and were qualitatively compared with those of the women who provided serial samples.

\section{Infant outcomes}

Medical records were reviewed to identify birth outcomes, infection, vaccination, growth, and developmental concerns in the infants who breastfed while their mothers were receiving rituximab from the time of birth to last well-child follow-up available. Weight, length, and head circumference recorded in medical records were compared with Centers for Disease Control and Prevention (CDC) clinical growth charts and reported as percentiles for age. ${ }^{18}$ The Ages and Stages Questionnaire $(\mathrm{ASQ} 3)^{19}$ was undertaken prospectively by parents at 4,8 , and 12 months of age. The ASQ3 is a questionnaire that evaluates 5 domains of child development, including gross motor, fine motor, communication, problemsolving, and personal-social development. Each domain is scored and categorized as "below cutoff," "monitoring zone," or "above cutoff." "Above cutoff" was considered normal because this indicates a child's development is on schedule. "Monitoring zone" means the child is close to the cutoff, and providing learning materials and monitoring is suggested. "Below cutoff" suggests professional assessment should be completed. 


\section{Data availability}

Anonymized data are available to qualified investigators on request for the purposes of replicating procedures or results by contacting the corresponding author.

\section{Results}

\section{Demographics and clinical characteristics}

Nine women with MS who entered the UCSF pregnancy registry for women with demyelinating diseases were treated clinically with rituximab while breastfeeding or shortly after weaning and agreed to provide breast milk samples. All had relapsing remitting MS with relatively mild disability (maximum EDSS of 2.0), with a mean age of 34 years and median disease duration of 4 years (table 1 ). Four women had also received rituximab in the 6 months before pregnancy, 1 received dimethyl fumarate before pregnancy, and 1 received fingolimod before pregnancy, followed by glatiramer acetate which was continued during pregnancy. The other 3 women had not received diseasemodifying therapy in the 6 months before pregnancy. The

Table 1 Patient demographics and clinical characteristics $(n=9)$

\begin{tabular}{ll}
\hline Characteristic & $\begin{array}{l}\text { Postpartum women } \\
(\mathbf{n}=\mathbf{9})\end{array}$ \\
\hline Age, mean y (SD) & $33.7(3.2)$ \\
\hline Weight, mean kg (SD) & $73.9(15.8)$ \\
\hline Disease duration, median y (range) & $4(0-11)$ \\
\hline MS subtype RRMS, $\mathbf{n}$ & 9 \\
\hline EDSS, median (range) & $0.0(0.0-2.0)$ \\
\hline Rituximab in $\mathbf{6}$ mo before pregnancy, $\mathbf{n}$ & 4 \\
\hline $\begin{array}{l}\text { Rituximab infusion to conception, median } \\
\text { mo (range) }\end{array}$ & $2.5(1.6-3.7)$ \\
\hline $\begin{array}{l}\text { Postpartum rituximab received, median mo } \\
\text { (range) }\end{array}$ & $6(1.5-11)$ \\
\hline Rituximab dose, $\mathbf{n}$ & \\
\hline $\mathbf{5 0 0}$ mg once & 2 \\
\hline $\mathbf{5 0 0 ~ m g ~ t w i c e ~ ( 2 . 7 ~ w k ~ a p a r t ) ~}$ & 1 \\
\hline $\mathbf{1 , 0 0 0 ~ m g ~ o n c e ~}$ & 5 \\
\hline $\mathbf{1 , 0 0 0}$ mg twice (2 wk apart) & 1 \\
\hline
\end{tabular}

No. of breast milk samples provided, $n$

\begin{tabular}{ll}
\hline $\mathbf{1}$ & 3 \\
\hline $\mathbf{2}$ & 2 \\
\hline $\mathbf{5}$ & 1 \\
\hline $\mathbf{6}$ & 3 \\
\hline
\end{tabular}

Abbreviations: EDSS = Expanded Disability Status Scale; RRMS = relapsing remitting MS. median time between delivery and rituximab treatment in the samples provided was 6 months, with a range from 1.5 to 11 months. Most patients received a single rituximab infusion of either 500 or $1,000 \mathrm{mg}$ IV. One individual received $500 \mathrm{mg}$ IV twice (19 days apart) with samples provided up to 19 days from the first infusion. Another had previously received rituximab $1,000 \mathrm{mg}$ twice 0.5 months postpartum and provided samples after the second dose of her second cycle of $1,000 \mathrm{mg}$ twice at 7 months postpartum.

\section{Rituximab concentration in breast milk}

The 9 women provided a total of 30 breast milk samples, with 4 patients providing at least 5 serial breast milk samples. The ICC calculated with 2 replicates was excellent (0.997). Concentrations of rituximab in breast milk measured in all samples are displayed in figure 1, and pharmacokinetic curves for the 4 patients with serial samples are shown in figure 2 . The median average rituximab concentration was low at $0.063 \mu \mathrm{g} / \mathrm{mL}$ (range 0.046-0.097) in the 4 patients who provided serial samples. Within these patients, the maximum rituximab concentration occurred between 1 and 7 days from the infusion, with a median maximum concentration of $0.074 \mu \mathrm{g} /$ $\mathrm{mL}$ (range 0.061-0.12). Based on the average concentration, the median absolute 24-hour daily dose of rituximab was $0.0094 \mathrm{mg} / \mathrm{kg} / \mathrm{d}$, and the median RID was $0.08 \%$ (range $0.06 \%-0.10 \%)$ (table 2).

Among the patients who provided 1-2 breast milk samples (feasibility and delayed samples), measured rituximab concentrations were generally similar to those of patients with serial samples apart from a single outlier with a rituximab concentration of $0.29 \mu \mathrm{g} / \mathrm{mL}$ at 11 days postinfusion (figure 1). This single outlier was a single sample provided by a mother who received rituximab $1,000 \mathrm{mg}$ at 9 months postpartum. To ensure that the RID was not underestimated, this higher value was also used to calculate the RID, and it remained low at $0.33 \%$. One patient provided samples more remote from the rituximab infusion at 60 and 90 days postinfusion. These values were reassuringly very low with a nearly undetectable level by 90 days. Rituximab levels in breast milk were not higher in mothers who also received rituximab before pregnancy or in the mother who received $1,000 \mathrm{mg}$ twice instead of a single infusion. Patient 3 (table 2 and figure 2C) had increasing rituximab levels at the last sample on day 19 with her second dose of rituximab on that same day, without capture of peak and decline after the second infusion.

\section{Infant outcomes}

Of the 9 women, 5 continued to breastfeed after receiving rituximab, whereas 4 discontinued breastfeeding before rituximab infusion. Of the 5 mothers who breastfed after receiving rituximab postpartum, 3 also received rituximab within the 6 months before pregnancy. Detailed information is available for 4 infants who breastfed after their mothers 


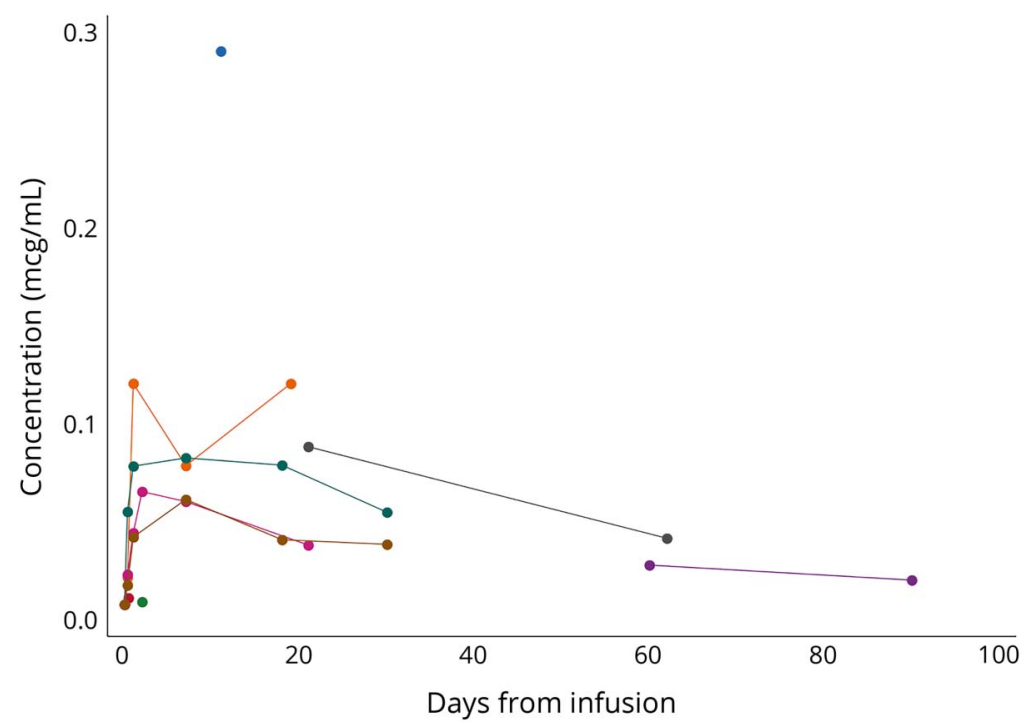

Rituximab concentrations $(\mu \mathrm{g} / \mathrm{mL})$ in 9 patients up to 90 days from infusion of rituximab 1,000 or 500 mg intravenous once or twice. Lines connect samples provided from a given individual. There was 1 outlier with a concentration of $0.29 \mu \mathrm{g} / \mathrm{mL}$ at 11 days postinfusion, although this level is still low.

received rituximab, whereas data were not available for the 1 other exposed infant (table 3 ). There were a few minor but no serious infections. The infant exposed to rituximab through breast milk earliest and with a higher total dose to the mother had more infections (table 3 , infant D), although none were serious and all were common infections seen in infancy. There were no preliminary concerns identified with growth or development up to 8-12 months postpartum in these infants, and routine vaccinations per CDC guidelines ${ }^{20}$ were given.

Figure 2 Pharmacokinetic curves for rituximab concentration in breast milk for patients who provided serial samples $(\mathrm{n}=4)$
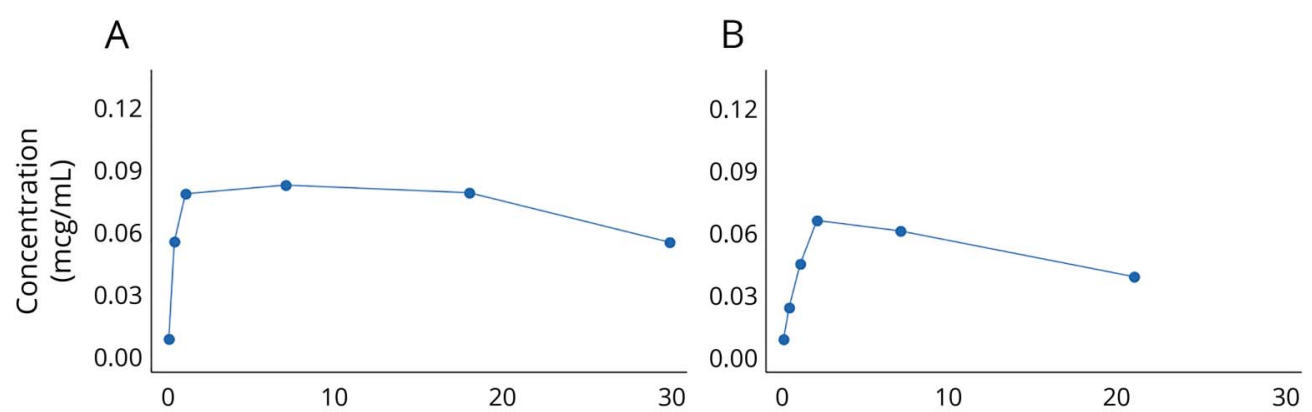

C

$\mathrm{D}$
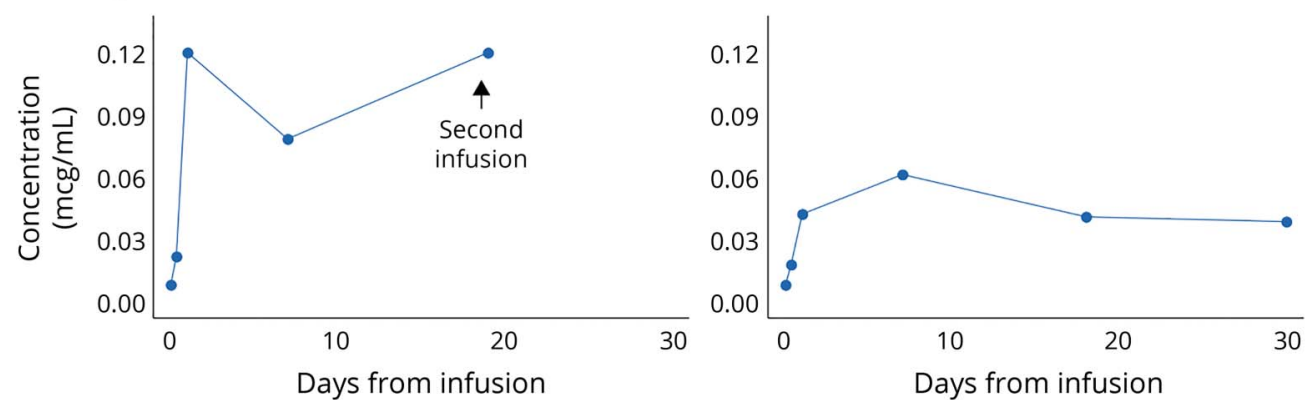

Rituximab concentrations ( $\mu \mathrm{g} / \mathrm{mL}$ ) in 4 patients up to 30 days after infusion of rituximab 1,000 mg IV once (A: patient 1; B: patient 2), 500 mg IV twice day 0 and 19 (C: patient 3), or 500 mg IV once (D: patient 4). IV = intravenous. 
Table 2 AUC, average concentration, maximum concentration, and RID of rituximab in breast milk among 4 patients with serial samples

\begin{tabular}{|c|c|c|c|c|c|}
\hline Parameters & Patient 1 & Patient 2 & Patient 3 & Patient 4 & Median (range) \\
\hline$A_{U C C_{0-T m a x}} \mu \mathrm{g} . \mathrm{d} / \mathrm{mL}$ & 2.23 & 1.08 & 1.84 & 1.37 & $1.61(1.08-2.23)$ \\
\hline Tmax, d & 30 & 21 & 19 & 30 & $25.5(19-30)$ \\
\hline Cavg, $\mu g / m L$ & 0.074 & 0.052 & 0.097 & 0.046 & $0.063(0.046-0.097)$ \\
\hline $\mathrm{Cmax}, \mu \mathrm{g} / \mathrm{mL}$ & 0.083 & 0.065 & 0.12 & 0.061 & $0.074(0.061-0.12)$ \\
\hline Time of Cmax, d & 7 & 2 & 1 & 7 & $4.5(1-7)$ \\
\hline Absolute infant dose by Cavg, $\mathrm{mg} / \mathrm{kg} / \mathrm{d}$ & 0.011 & 0.0077 & 0.015 & 0.0068 & $0.0094(0.0068-0.015)$ \\
\hline Absolute infant dose by $\mathrm{Cmax}, \mathrm{mg} / \mathrm{kg} / \mathrm{d}$ & 0.012 & 0.0098 & 0.018 & 0.0092 & $0.011(0.0092-0.018)$ \\
\hline RID from Cavg, \% & 0.065 & 0.057 & 0.092 & 0.099 & $0.079(0.057-0.099)$ \\
\hline RID from Cmax, \% & 0.072 & 0.072 & 0.11 & 0.13 & $0.094(0.072-0.13)$ \\
\hline Rituximab dose, mg & $1,000 \times 1$ & $1,000 \times 1$ & $500 \times 2$ & $500 \times 1$ & $1,000(500-1,000)$ \\
\hline Time of rituximab postpartum, mo & 6 & 4 & 6 & 11 & $6(4-11)$ \\
\hline Maternal weight, kg & 58.4 & 73.5 & 63.5 & 72.6 & $68.1(58.4-73.5)$ \\
\hline Breast milk samples, $n$ & 6 & 6 & 5 & 6 & $6(5-6)$ \\
\hline $\begin{array}{l}\text { Timing of breast milk samples after } \\
\text { rituximab infusion }\end{array}$ & $\begin{array}{l}0,8 \mathrm{~h}, 24 \mathrm{~h}, 7 \mathrm{~d} \\
18 \mathrm{~d}, 30 \mathrm{~d}\end{array}$ & $\begin{array}{l}0,8 \mathrm{~h}, 24 \mathrm{~h}, 48 \mathrm{~h}, \\
7 \mathrm{~d}, 18 \mathrm{~d}\end{array}$ & $\begin{array}{l}0,8 \mathrm{~h}, 24 \mathrm{~h}, 7 \mathrm{~d} \\
19 \mathrm{~d}\end{array}$ & $\begin{array}{l}0,8 \mathrm{~h}, 24 \mathrm{~h}, 7 \mathrm{~d} \\
18 \mathrm{~d}, 30 \mathrm{~d}\end{array}$ & \\
\hline
\end{tabular}

Abbreviations: $\mathrm{AUC}=$ area under the drug-concentration-time curve in milk; Cavg = average drug concentration over the interval; $\mathrm{Cmax}=$ maximum drug concentration measured; RID = relative infant dose; Tmax = maximum time of milk collection .

RID values are in bold because these are values of greatest importance.

\section{Discussion}

In this prospective cohort study of postpartum women with MS receiving rituximab, we observed very low transfer of rituximab into mature breast milk. The average and maximum concentrations of rituximab in breast milk were reassuringly low and reached nearly undetectable levels by 60-90 days from the infusion. The median RID was $0.08 \%$ and maximum RID was $0.10 \%$, both less than the acceptable value of less than $10 \% .{ }^{17}$ Furthermore, the small amount of rituximab reaching the breast milk is likely degraded in the infant's GI tract, ${ }^{8}$ with less than $25 \%$ of ingested $\operatorname{IgG}$ reaching the stool and the remainder presumably digested. ${ }^{21}$ The neonatal $\mathrm{Fc}_{\mathrm{c}}$ receptor may allow passage of these undigested IgG molecules from the GI tract to circulation, ${ }^{22}$ and so a small amount of infant exposure cannot be excluded.

The low concentrations of rituximab measured in mature breast milk in our study were consistent with the low concentration reported in the single case of vasculitis treated with rituximab during breastfeeding. ${ }^{16}$ With serial sampling of breast milk from 4 mothers, we were able to calculate area under the breast milk concentration-time curve, allowing calculation of the average concentration and RID which were reassuring. Although the levels varied between patients, with a slightly higher maximum concentration in 1 woman treated with $500 \mathrm{mg}$ (figure $2 \mathrm{C}$, patient
3) compared with others who received $1,000 \mathrm{mg}$ rituximab, the concentrations were overall quite similar and reassuringly low. It is possible there may be minor interindividual variability in the pharmacokinetics and breast milk transfer of rituximab.

Recent studies in inflammatory bowel disease evaluated concentrations of other monoclonal antibodies in breast milk, including tumor necrosis factor-alpha inhibitors, and found reassuringly low peak concentrations. ${ }^{23,24}$ Natalizu$\mathrm{mab}$, an $\mathrm{IgG}_{4}$ monoclonal antibody therapy for MS and inflammatory bowel disease, represents 1 notable exception because of more repeated dosing and the higher relative proportion of $\mathrm{IgG}_{4}$ in mature breast milk than in serum. $^{25,26}$ Although low levels of natalizumab were reported in breast milk in 2 patients, ${ }^{23}$ serial collection of breast milk over 50 days from infusion in another single patient suggested accumulation of natalizumab in breast milk. ${ }^{27}$ By contrast, rituximab can be dosed once every 6-12 months and is an $\mathrm{IgG}_{1}$ subclass with a large molecular weight $(145 \mathrm{kD}){ }^{28} \mathrm{IgG}_{1}$ transfers in low levels into mature milk, ${ }^{26}$ which is consistent with our finding of lower breast milk transfer of rituximab than that reported with natalizumab.

Regarding pregnancy and neonatal outcomes with maternal treatment with rituximab, a case series of 11 pregnancies in women who received rituximab within 6 months of 
Table 3 Outcomes for infants born to mothers treated with rituximab during breastfeeding

\begin{tabular}{|c|c|c|c|c|}
\hline Characteristics & Infant A & Infant B & Infant C & Infant D \\
\hline $\begin{array}{l}\text { Time from last rituximab to } \\
\text { conception, mo }\end{array}$ & 1.6 & 2.3 & 3.7 & None \\
\hline $\begin{array}{l}\text { Time of postpartum } \\
\text { rituximab infusion, } \mathrm{mo}^{\mathrm{a}}\end{array}$ & 2.6 & 4 & 6 & 0.5 and 7 \\
\hline DMT in pregnancy & None & None & None & Glatiramer acetate \\
\hline Sex & $\mathrm{F}$ & $\mathrm{F}$ & M & $\mathrm{F}$ \\
\hline Gestational age & $38 w k 6 d$ & 39 wk $4 d$ & $41 \mathrm{wk}$ & $37 w k 3 d$ \\
\hline Delivery method & SVD & $\begin{array}{l}\text { SVD } \\
\text { assisted }\end{array}$ & SVD assisted & SVD \\
\hline Perinatal complications & None & None & $2 \mathrm{BRUE}^{\mathrm{b}}$ & None \\
\hline $\begin{array}{l}\text { Breastfeeding mo after } \\
\text { postpartum rituximab }\end{array}$ & $\begin{array}{l}\text { Discarded } 2 \text { mo then BF } \\
4 \text { mo }\end{array}$ & $5 \mathrm{mo}$ & $2 \mathrm{mo}$ & $11.5 \mathrm{mo}$ \\
\hline Growth, timing & $9 \mathrm{mo}^{\mathrm{c}}$ & $9 \mathrm{mo}^{\mathrm{c}}$ & $6 \mathrm{mo} 1 \mathrm{wk}^{\mathrm{c}}$ & $5 \mathrm{mo}^{\mathrm{c}}$ \\
\hline Weight, CDC percentile & $50-75$ th & $50-75$ th & 75-90th & 50th \\
\hline Height, CDC percentile & 50th & 75-90th & 75-90th & 75-90th \\
\hline $\begin{array}{l}\text { Head circumference, } C D C \\
\text { percentile }\end{array}$ & 75-90th & 25-50th & 90-95th & 25-50th \\
\hline Infections & $\begin{array}{l}2 \mathrm{wk}^{\mathrm{d}} \text { : Conjunctivitis } \\
\text { and dacryostenosis }\end{array}$ & $\begin{array}{l}7 \mathrm{moc}: \\
\text { Fever }\end{array}$ & $\begin{array}{l}5 \mathrm{mo}^{\mathrm{d}}: \text { URTI and } \\
\text { otitis media }\end{array}$ & $\begin{array}{l}3 \text { wk }^{\mathrm{c}} \text { : GERD and esophagitis; } 2 \mathrm{mo}^{\mathrm{c}} \text { : URTI; } 3 \mathrm{mo}^{\mathrm{c}} \text { : URTI and } \\
\text { diarrhea; } 11 \mathrm{mo}^{\mathrm{c}} \text { : Fever; } 12 \mathrm{mo}^{\mathrm{c}} \text { : URTI }\end{array}$ \\
\hline Routine vaccinations ${ }^{\mathrm{e}}$ & Complete & $\begin{array}{l}\text { Complete } \\
\text { except RV }\end{array}$ & Complete & Complete \\
\hline $\begin{array}{l}\text { Development at well-child } \\
\text { visits }\end{array}$ & Normal & Normal & Normal & Normal \\
\hline ASQ $^{f}$ & $4 \mathrm{mo}^{\mathrm{d}} / 8 \mathrm{mo}^{\mathrm{c}}$ & $4 \mathrm{mo}^{\mathrm{c}}$ & $4 \mathrm{mo}^{\mathrm{d}} / 8 \mathrm{mo}^{\mathrm{c}}$ & $8 \mathrm{mo}^{\mathrm{c}} / 12 \mathrm{mo}^{\mathrm{c}}$ \\
\hline Gross motor & Above/above & Above & Above/above & Above/above \\
\hline Fine motor & Above/above & Above & Above/above & Above/above \\
\hline Communication & Monitor/above & Above & Above/above & Above/above \\
\hline Problem-solving & Above/above & Above & Above/above & Above/above \\
\hline Personal-social & Above/above & Above & Above/above & Above/above \\
\hline Follow-up, mo & 9 & 9 & 8 & 12 \\
\hline
\end{tabular}

Abbreviations: $\mathrm{ASQ3}=$ Ages and Stages Questionnaire; BF = breastfed; BRUE = brief resolved unexplained events; $C D C=$ Centers for Disease Control and Prevention; DMT = disease-modifying therapy; GERD = gastroesophageal reflux disease; RV = rotavirus; SVD = spontaneous vaginal delivery; URTI = upper respiratory tract infection.

a $1,000 \mathrm{mg} \times 1$ in infants $\mathrm{A}, \mathrm{B}, \mathrm{C} ; 1,000 \mathrm{mg} \times 2$ at $0.5 \mathrm{mo}$ and $7 \mathrm{mo}$ in infant $\mathrm{D}$.

${ }^{\mathrm{b}} 2$ brief resolved unexplained events of color changes while breastfeeding during the first $\mathrm{d}$ of life, but was monitored with no additional complications.

'Time point after postpartum rituximab received by the mother and breastfeeding.

${ }^{\mathrm{a}}$ Time point before postpartum rituximab received by the mother and breastfeeding.

e Vaccinations as per CDC guidelines ${ }^{20}$ up to 9 mo of age include diphtheria, tetanus, and acellular pertussis (DTaP), Haemophilus influenzae type b (Hib), pneumococcal conjugate (PCV13), inactivated poliovirus (IPV), hepatitis B (HepB), Rotavirus (RV1 or RV5), and influenza (IIV). Only infant D had reached the age at which CDC recommends live vaccination against measles, mumps, and rubella (MMR), and this was given routinely. None had yet received varicella vaccination because of their age.

f The ASQ3 evaluates 5 domains of child development: gross motor, fine motor, communication, problem-solving, and personal-social development. Each domain is scored and categorized as "below cutoff," "monitoring zone" (Monitor), or "above cutoff" (Above). "Above cutoff" means child development is on schedule in the given domain. Eight-month ASQ3 is missing for infant B and 4-month ASQ3 is missing for infant D.

conception for MS and NMOSD, as well as a systematic review of women treated for other conditions, did not identify any major safety concerns. ${ }^{29}$ The patients included in our study were clinically treated with rituximab while breastfeeding, despite its off-label use in MS, likely based on pregnancy safety data ${ }^{29}$ and the reassuring single case report of a low breast milk rituximab concentration in a patient treated for vasculitis. ${ }^{16}$ Because patients were being treated clinically, this provided the opportunity to measure the breast milk concentration of rituximab to help guide future treatment decision-making in the postpartum period. 
Four mothers in our cohort breastfed after receiving rituximab and provided growth, development, and medical records for their infants, which demonstrated no serious infections and normal growth and development in these infants followed up to 8-12 months of age. Even the infant whose mother received the highest total dose of rituximab early in the postpartum period and who experienced the most infections was well within the normal range of expected infections. ${ }^{30} \mathrm{Un}$ fortunately, the small sample size and lack of a comparison group precluded rigorous determination as to whether the number of infections differed from expected. The effect of postpartum rituximab timing and dose on infant outcomes requires further study.

Limitations of this study include the relatively small number of breast milk samples, although collection of serial milk samples in 4 women did allow calculation of fairly consistent AUC and RID. Unfortunately, serial breast milk collection at the preferred time points was not available in all treated women because data were collected during real-world use of rituximab and not all participants were identified at the time of rituximab treatment. In addition, we were unable to capture the declining concentration of rituximab over time after a cycle containing 2 infusions (patient 3 ) because of a lack of sample collection after the second infusion. There were also limited safety data in infants who continued to breastfeed after rituximab treatment, with a relatively short follow-up in 4 infants. Unfortunately, blood samples from infants who breastfed after their mothers received rituximab were not available, so we could not assess rituximab concentration or the biological effect of any possible rituximab exposure in the infants, such as blood counts, $\mathrm{CD} 19^{+} \mathrm{B}$ cell counts, or response to vaccination.

We expect that our findings would generalize to the use of rituximab more broadly during breastfeeding; however, some special cases must be considered. Maternal complications such as mastitis might allow greater transfer of large molecules such as rituximab into breast milk. ${ }^{7}$ Our findings may also not apply to breast milk in the first 14 days of life, given the differences in the contents of colostrum and transitional milk compared with mature breast milk. Finally, in preterm infants, gut immaturity could affect absorption of rituximab.

Further studies are required to evaluate the long-term infant safety of rituximab treatment during breastfeeding, including evaluation of the biological effect on lymphocyte subsets and response to vaccination. Further study is also required to understand whether maternal treatment with rituximab alters the composition of breast milk because IgA is a major immunologic component of breast milk, ${ }^{8}$ and immunoglobulins may be depleted with long-term rituximab treatment. ${ }^{31}$ It is also not known whether the neonatal gut microbiome could be affected by rituximab exposure in breast milk. Ocrelizumab, another anti-CD20 monoclonal antibody that is Food and Drug Administration-approved for $\mathrm{MS}$, is also an $\operatorname{IgG}_{1}$ molecule of the same molecular size as rituximab (145 $\mathrm{kDa}),{ }^{32}$ and therefore, we would expect similarly low ocrelizumab transfer into breast milk. To investigate this, our ongoing registry efforts will enable direct measurement of ocrelizumab concentration in breast milk.

Altogether, our findings suggest that at least in the mature milk phase in term infants, a single rituximab infusion results in a RID in breast milk of less than $0.4 \%$ in all cases, which is far less than the commonly accepted threshold of $10 \%$. These findings are appealing for women with a higher risk of disease activity in the postpartum state (such as MS or NMOSD relapse, which may be associated with disability progression, ${ }^{33}$ and refractory autoimmune myasthenia gravis or autoimmune encephalitis). In individual cases, the significant benefit of maintaining neurologic stability in the mother with the help of monoclonal antibodies could offset theoretical risks to the infant, allowing both mother and infant to benefit from breastfeeding. ${ }^{6}$ Areas requiring further study include evaluating drug concentrations and lymphocyte counts in infants exposed to drug-containing breast milk and studying longerterm developmental data in these infants. Larger prospective registry studies are ongoing.

\section{Acknowledgment}

The authors would like to thank the women who donated their breast milk and participated in this study.

\section{Study funding}

National Multiple Sclerosis Society Career Transition Award. K.M. Krysko is funded by a Sylvia Lawry Physician Fellowship from the National Multiple Sclerosis Society (FP-1605-08753 (Krysko)).

\section{Disclosures}

K.M. Krysko receives fellowship support from the National MS Society and from Biogen. S.C. LaHue reports no disclosures. A. Anderson reports no disclosures. A. Rutatangwa receives fellowship support from Biogen. W. Rowles reports no disclosures. R.D. Schubert receives fellowship support from the National Multiple Sclerosis Society and American Brain Foundation Clinician Scientist Development Award (FAN-1608-25607) and has received advisory board fees from Genzyme-Sanofi. J. Marcus reports no disclosures. C.S. Riley has received consulting and advisory board fees from Biogen, Roche-Genentech, TG Therapeutics, and EMD Serono. C. Bevan reports no disclosures. T.W. Hale is a consultant for Biohaven Pharmaceuticals. R. Bove has received consulting and advisory board fees from Alexion, Biogen, EMD Serono, Genzyme-Sanofi, Novartis, and RocheGenentech. The authors have no conflicts of interest relevant to this article to disclose. Go to Neurology.org/NN for full disclosures.

\section{Publication history}

Received by Neurology: Neuroimmunology \& Neuroinflammation August 26, 2019. Accepted in final form October 1, 2019. 
Appendix Authors

\begin{tabular}{|c|c|c|c|}
\hline Name & Location & Role & Contribution \\
\hline $\begin{array}{l}\text { Kristen M. } \\
\text { Krysko, MD, } \\
\text { MAS }\end{array}$ & $\begin{array}{l}\text { University of } \\
\text { California, San } \\
\text { Francisco }\end{array}$ & Author & $\begin{array}{l}\text { Designed and } \\
\text { conceptualized the study, } \\
\text { analyzed and interpreted } \\
\text { the data, and drafted the } \\
\text { manuscript for intellectual } \\
\text { content }\end{array}$ \\
\hline
\end{tabular}

\begin{tabular}{llll}
\hline Sara C. & University of & Author & $\begin{array}{l}\text { Designed and } \\
\text { conceptualized the study, } \\
\text { interpreted the data, and } \\
\text { drafted the manuscript for } \\
\text { intellectual content }\end{array}$ \\
& California, San & &
\end{tabular}

\begin{tabular}{llrl}
\hline Annika & $\begin{array}{l}\text { University of } \\
\text { Anderson, BA }\end{array}$ & Aalifornia, San \\
Francisco & Major role in the \\
& & $\begin{array}{l}\text { acquisition of data and } \\
\text { revised the manuscript for } \\
\text { intellectual content }\end{array}$
\end{tabular}

\begin{tabular}{llll}
\hline $\begin{array}{l}\text { Alice } \\
\text { Rutatangwa, } \\
\text { DO, MSc }\end{array}$ & $\begin{array}{l}\text { University of } \\
\text { California, San } \\
\text { Francisco }\end{array}$ & Author & $\begin{array}{l}\text { Designed and } \\
\text { conceptualized the study } \\
\text { and revised the manuscript } \\
\text { for intellectual content }\end{array}$ \\
\hline $\begin{array}{l}\text { William } \\
\text { Rowles, BA }\end{array}$ & $\begin{array}{l}\text { University of } \\
\text { California, San } \\
\text { Francisco }\end{array}$ & Author & $\begin{array}{l}\text { Major role in the } \\
\text { acquisition of data }\end{array}$ \\
\hline $\begin{array}{l}\text { Ryan } \\
\text { Schubert, } \\
\text { MD }\end{array}$ & $\begin{array}{l}\text { University of } \\
\text { California, San }\end{array}$ & Author & $\begin{array}{l}\text { Designed and } \\
\text { conceptualized the study } \\
\text { and revised the manuscript } \\
\text { for intellectual content }\end{array}$ \\
\hline $\begin{array}{l}\text { Jacqueline } \\
\text { Marcus, MD }\end{array}$ & $\begin{array}{l}\text { Kaiser } \\
\text { Permanente }\end{array}$ & Author & $\begin{array}{l}\text { Major role in the } \\
\text { acquisition of data and } \\
\text { revised the manuscript for } \\
\text { intellectual content }\end{array}$ \\
\hline
\end{tabular}

\begin{tabular}{|c|c|c|c|}
\hline $\begin{array}{l}\text { Claire S. } \\
\text { Riley, MD }\end{array}$ & $\begin{array}{l}\text { Columbia } \\
\text { University }\end{array}$ & Author & $\begin{array}{l}\text { Major role in the } \\
\text { acquisition of data and } \\
\text { revised the manuscript for } \\
\text { intellectual content }\end{array}$ \\
\hline
\end{tabular}

\begin{tabular}{|c|c|c|c|}
\hline $\begin{array}{l}\text { Carolyn } \\
\text { Bevan, MD, } \\
\text { MS }\end{array}$ & $\begin{array}{l}\text { Northwestern } \\
\text { University }\end{array}$ & Author & $\begin{array}{l}\text { Major role in the } \\
\text { acquisition of data and } \\
\text { revised the manuscript for } \\
\text { intellectual content }\end{array}$ \\
\hline
\end{tabular}

\begin{tabular}{|c|c|c|c|}
\hline $\begin{array}{l}\text { Thomas W. } \\
\text { Hale, RPh, } \\
\text { PhD }\end{array}$ & $\begin{array}{l}\text { Texas Tech } \\
\text { University } \\
\text { School of } \\
\text { Medicine }\end{array}$ & Author & $\begin{array}{l}\text { Reviewed and interpreted } \\
\text { the data and revised the } \\
\text { manuscript for intellectual } \\
\text { content }\end{array}$ \\
\hline $\begin{array}{l}\text { Riley Bove, } \\
\text { MD, MSc }\end{array}$ & $\begin{array}{l}\text { University of } \\
\text { California, San } \\
\text { Francisco }\end{array}$ & Author & $\begin{array}{l}\text { Designed and } \\
\text { conceptualized the study, } \\
\text { major role in the } \\
\text { acquisition of data, } \\
\text { interpreted the data, and } \\
\text { revised the manuscript for } \\
\text { intellectual content }\end{array}$ \\
\hline
\end{tabular}

\section{References}

1. Gelfand JM, Cree BAC, Hauser SL. Ocrelizumab and other CD20+ B-cell-depleting therapies in multiple sclerosis. Neurotherapeutics 2017;14:835-841.

2. Nguyen A-L, Gresle M, Marshall T, Butzkueven H, Field J. Monoclonal antibodies in the treatment of multiple sclerosis: emergence of B-cell-targeted therapies. $\mathrm{Br} J$ Pharmacol 2017;174:1895-1907.

3. Shin YW, Lee ST, Park KI, et al. Treatment strategies for autoimmune encephalitis. Ther Adv Neurol Disord 2017;11:1756285617722347.

4. Mantegazza R, Antozzi C. When myasthenia gravis is deemed refractory: clinical signposts and treatment strategies. Ther Adv Neurol Disord 2018;11: 1756285617749134 .

5. Loder EW, Robbins MS. Monoclonal antibodies for migraine prevention: progress, but not a panacea. JAMA 2018;319:1985-1987.
6. Breastfeeding SO. Breastfeeding and the use of human milk. Pediatrics 2012;129: e827-e841.

7. Anderson PO, Sauberan JB. Modeling drug passage into human milk. Clin Pharmacol Ther 2016;100:42-52.

8. Hurley WL, Theil PK. Perspectives on immunoglobulins in colostrum and milk. Nutrients 2011;3:442-474.

9. Wang J, Johnson T, Sahin L, et al. Evaluation of the safety of drugs and biological products used during lactation: workshop summary. Clin Pharmacol Ther 2017;101: 736-744.

10. Pistilli B, Bellettini G, Giovannetti E, et al. Chemotherapy, targeted agents, antiemetics and growth-factors in human milk: how should we counsel cancer patients about breastfeeding? Cancer Treat Rev 2013;39:207-211.

11. Reproductive Health in Rheumatic Diseases. Available at: rheumatology.org/PracticeQuality/Clinical-Support/Clinical-Practice-Guidelines/Reproductive-Health-inRheumatic-Diseases. Accessed May 31, 2019.

12. Mahadevan U, Robinson C, Bernasko N, et al. Inflammatory bowel disease in pregnancy clinical care pathway: a report from the American gastroenterological association IBD parenthood project working group. Gastroenterology 2019;156: $1508-1524$

13. Granqvist M, Boremalm M, Poorghobad A, et al. Comparative effectiveness of rituximab and other initial treatment choices for multiple sclerosis. JAMA Neurol 2018; 75:320-327.

14. Hauser SL, Waubant E, Arnold DL, et al. B-cell depletion with rituximab in relapsingremitting multiple sclerosis. N Engl J Med 2008;358:676-688.

15. Iorio R, Damato V, Alboini PE, Evoli A. Efficacy and safety of rituximab for myasthenia gravis: a systematic review and meta-analysis. J Neurol 2015;262:1115-1119.

16. Bragnes Y, Boshuizen R, de Vries A, Lexberg Å, Østensen M. Low level of Rituximab in human breast milk in a patient treated during lactation. Rheumatology (Oxford) 2017;56:1047-1048.

17. Bennett P. Drugs and Human Lactation: A Comprehensive Guide to the Content and Consequences of Drugs, Micronutrients, Radiopharmaceuticals and Environmental and Occupational Chemicals in Human Milk, 2nd ed. Amsterdam, The Netherlands: Elsevier; 1996.

18. Growth Charts-Clinical Growth Charts; 2000. Available at: cdc.gov/growthcharts/ clinical charts.htm. Accessed June 4, 2019.

19. Squires J, Bricker D. Ages \& Stages Questionnaires[R], 3rd ed, (ASQ-3[TM]): A Parent-Completed Child-Monitoring System. Baltimore, MD: Brookes Publishing Company; 2009.

20. Centers for Disease Control and Prevention (CDC). Immunization Schedules. Centers for Disease Control and Prevention (CDC). Available at: cdc.gov/vaccines/ schedules/hcp/imz/child-adolescent.html. Published February 5, 2019. Accessed September 3, 2019.

21. Jasion VS, Burnett BP. Survival and digestibility of orally-administered immunoglobulin preparations containing IgG through the gastrointestinal tract in humans. Nutr J 2015;14:22.

22. Giragossian C, Clark T, Piché-Nicholas N, Bowman CJ. Neonatal Fc receptor and its role in the absorption, distribution, metabolism and excretion of immunoglobulin G-based biotherapeutics. Curr Drug Metab 2013;14:764-790.

23. Matro R, Martin CF, Wolf D, Shah SA, Mahadevan U. Exposure concentrations of infants breastfed by women receiving biologic therapies for inflammatory bowel diseases and effects of breastfeeding on infections and development. Gastroenterology 2018;155:696-704.

24. Clowse ME, Förger F, Hwang C, et al. Minimal to no transfer of certolizumab pegol into breast milk: results from CRADLE, a prospective, postmarketing, multicentre, pharmacokinetic study. Ann Rheum Dis 2017;76:1890-1896.

25. Keller MA, Heiner DC, Kidd RM, Myers AS. Local production of IgG4 in human colostrum. J Immunol 1983;130:1654-1657.

26. Rodríguez-Camejo C, Puyol A, Fazio L, et al. Antibody profile of colostrum and the effect of processing in human milk banks: implications in immunoregulatory properties. J Hum Lact 2018;34:137-147.

27. Baker TE, Cooper SD, Kessler L, Hale TW. Transfer of natalizumab into breast milk in a mother with multiple sclerosis. J Hum Lact 2015;31:233-236.

28. Genentech Rituxan (rituximab) [package insert]. U.S. Food and Drug Administration. Available at: accessdata.fda.gov/drugsatfda docs/label/2010/103705s5311lbl. pdf. Published Revised 2010. Accessed May 21, 2019.

29. Das G, Damotte V, Gelfand JM, et al. Rituximab before and during pregnancy: a systematic review, and a case series in MS and NMOSD. Neurol Neuroimmunol Neuroinflammation 2018;5:e453. doi:10.1212/NXI.0000000000000453.

30. McInerny TK, Adam HM, Campbell DE, DeWitt TG, Foy JM, Kamat DM, eds. American Academy of Pediatrics Textbook of Pediatric Care. 2nd ed. Elk Grove Village, IL: American Academy of Pediatrics; 2017.

31. Kado R, Sanders G, McCune WJ. Suppression of normal immune responses after treatment with rituximab. Curr Opin Rheumatol 2016;28:251-258.

32. Genentech. Ocrevus(ocrelizumab) [package insert].U.S. Food and Drug Administration website. Available at: accessdata.fda.gov/drugsatfda_docs/label/2017/ 761053lbl.pdf. Published Revised 2017. Accessed August 30, 2019.

33. Portaccio E, Ghezzi A, Hakiki B, et al. Postpartum relapses increase the risk of disability progression in multiple sclerosis: the role of disease modifying drugs. J Neurol Neurosurg Psychiatry 2014;85:845-850. 


\title{
Neurology \\ Neuroimmunology \& Neuroinflammation
}

\author{
Minimal breast milk transfer of rituximab, a monoclonal antibody used in neurological \\ conditions \\ Kristen M. Krysko, Sara C. LaHue, Annika Anderson, et al. \\ Neurol Neuroimmunol Neuroinflamm 2020;7; \\ DOI 10.1212/NXI.0000000000000637
}

This information is current as of November 12, 2019

\begin{abstract}
Updated Information \&
Services

References

Citations

Subspecialty Collections

Permissions \& Licensing

Reprints

including high resolution figures, can be found at: http://nn.neurology.org/content/7/1/e637.full.html

This article cites 25 articles, 3 of which you can access for free at: http://nn.neurology.org/content/7/1/e637.full.html\#\#ref-list-1

This article has been cited by 1 HighWire-hosted articles: http://nn.neurology.org/content/7/1/e637.full.html\#\#otherarticles

This article, along with others on similar topics, appears in the following collection(s):

Autoimmune diseases

http://nn.neurology.org//cgi/collection/autoimmune_diseases Multiple sclerosis

http://nn.neurology.org//cgi/collection/multiple_sclerosis its entirety can be found online at:

http://nn.neurology.org/misc/about.xhtml\#permissions

Information about ordering reprints can be found online:

http://nn.neurology.org/misc/addir.xhtml\#reprintsus
\end{abstract}

Information about reproducing this article in parts (figures,tables) or in

Neurol Neuroimmunol Neuroinflamm is an official journal of the American Academy of Neurology.

Published since April 2014, it is an open-access, online-only, continuous publication journal. Copyright

Copyright (C) 2019 The Author(s). Published by Wolters Kluwer Health, Inc. on behalf of the American

Academy of Neurology.. All rights reserved. Online ISSN: 2332-7812.

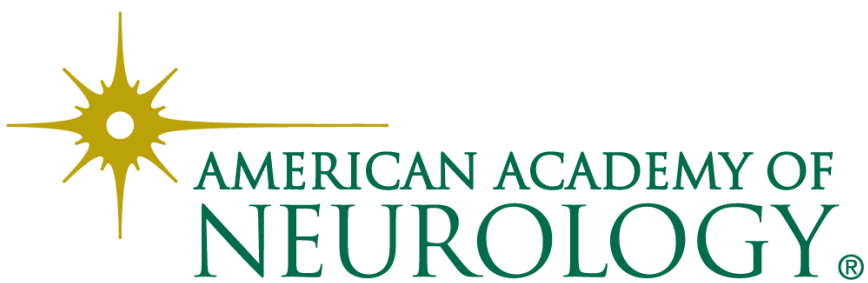

